\title{
Diretivas ANTECIPADAS DE VONTADE: NOVOS DESAFIOS PARA A COMPREENSÃO DO SISTEMA JURÍDICO PELA CONSAGRAÇÃO DO INSTITUTO DA REPRESENTAÇÃO VOLUNTÁRIA EM MATÉRIA DE DIREITOS DE PERSONALIDADE
}

Patrícia Cardoso Dias*

\begin{abstract}
1 Introdução. 2 A Doutrina da Alternativa Menos Restritiva de Direitos. 3 Da Dignidade da Pessoa Humana e da Autodeterminação. 4 O Direito Subjetivo de Personalidade. 5 Procurador de Cuidados de Saúde. 6 Desfuncionalização do Princípio da Intransmissibilidade dos Direitos de Personalidade. 7 Conclusões. Referências.
\end{abstract}

\section{RESUMO}

As diretivas antecipadas de vontade foram expressamente reconhecidas no ordenamento jurídico português, com a aprovação da Lei $N^{0}$ 25/2012, de 16 de julho. A aprovação dessa lei trouxe novos desafios para a compreensão do sistema jurídico, designadamente, pela consagração da representação voluntária em matéria de cuidados de saúde. Em uma época em que a autonomia é objeto de uma valorização crescente, esse instrumento se apresenta como um profícuo mecanismo de resposta a uma incapacidade específica limitada à área da saúde: a expressão da vontade. As decisões médicas incidem sobre o núcleo fundamental da personalidade física e psíquica, o que determinaria o exercício do direito pelo seu titular. Convoca, assim, uma figura jurídica sensível: os direitos de personalidade. Os direitos de personalidade enformam a pessoa e tutelam elementos concretos da pessoa. O consentimento ou dissentimento prospetivo para uma intervenção médica, concretizado nas diretivas, tem por objeto esses elementos concretos da pessoa. Da limitação de direitos de personalidade, mesmo quando admitida nos termos do art. 81 do CC, não pode resultar a sua transmissão, pois aqueles são intransmissíveis. Com efeito, tendo presente que o poder sobre os bens da personalidade, apenas pode pertencer à pessoa relativamente à qual se encontram integrados, esse instrumento vem legitimar a atuação de outrem sobre os bens da personalidade alheia, no

* Mestre em Ciências Jurídico-Processuais pela Universidade Autónoma de Lisboa "Luís de Camões”. E-mail: <dias.patriciacardoso@gmail.com>. 
momento em que a pessoa não consegue beneficiar ou cuja capacidade de beneficiar destes, tornando-se necessário que seja esse representante, na específica área da saúde, a exercer um poder específico sobre aqueles, no interesse do respetivo titular.

Palavras-chave: Diretivas Antecipadas de Vontade. Consentimento Informado. Autonomia Prospetiva. Procurador em Cuidados de Saúde.

\section{INTRODUÇÃO}

As diretivas antecipadas de vontade, acompanhando Yvon Kenis e Helena Pereira de Melo na esteira daquela, são

instruções que uma pessoa dá antecipadamente, relativas a tratamentos que deseja ou (mais frequentemente) que recusa receber no fim da vida, para o caso de se tornar incapaz de exprimir as suas vontades ou de tomar decisões por e para si própria. ${ }^{1}$

Assumindo fundamentalmente duas formas, o testamento vital e a nomeação de um procurador em cuidados de saúde, o ordenamento jurídico português veio receber essas duas modalidades de diretivas antecipadas de vontade, com a aprovação da Lei $\mathrm{N}^{\mathrm{O}}$ 25/2012, de 16 de julho. ${ }^{2}$

As declarações antecipadas de vontade são, nesse sentido, a forma de assegurar que, depois de incapacitados a exprimirmos a nossa vontade real de sermos submetidos, ou não, a alguma intervenção médica, seremos nós, ainda assim, a decidir sobre o destino da nossa vida e do nosso corpo.

Expressão máxima da autonomia do indivíduo enquanto ser único e irrepetível, é também um mecanismo de salvaguarda do respeito pela dignidade da pessoa humana, de cada pessoa individualmente considerada e do projeto de vida que para si idealizou.

Em bom rigor, as mais fundamentais decisões da vida de cada um devem ser tomadas pelo próprio que, concomitantemente, deve chamar a si a responsabilidade por tais decisões. Trata-se da consagração da ética da responsabilidade de que fala Rui Nunes. ${ }^{3}$

O conceito de autonomia refere-se à perspectiva de que cada ser humano deve dispor das condições mínimas para se autorrealizar. No plano da relação clínica com o doente, todas as intervenções carecem de consentimento informado, livre e esclarecido [...] Enquadra-se, ainda, no direito à autodeterminação o respeito que merece a vontade doente, previamente manifestada. ${ }^{4}$

Com efeito, entendemos que a consagração, no ordenamento jurídico português, das diretivas antecipadas de vontade se encontra subjacente à ideia de respeito pela dignidade da pessoa humana, na sua vertente de prossecução de cumprir e salvaguardar a autonomia prospetiva do paciente, resultante da 
progressiva rejeição do paternalismo médico e destaque progressivamente conferido à autonomia do paciente no processo de decisão em relação aos cuidados de saúde que deseja, ou não, receber.

Pretendemos, com a nossa reflexão, contribuir para a discussão dogmática concernente ao respeito pela vontade manifestada sobre a esfera física e psíquica da pessoa humana e a proteção desta, que se encontra sob tutela do direito geral de personalidade ( art. $^{\circ} 70$ do Código Civil, doravante designado CC): ${ }^{5}$ deste decorrem outros direitos especiais de personalidade. Referimo-nos ao direito à vida, o direito à integridade física e psíquica e o direito à autodeterminação em matéria de cuidados de saúde.

É profícuo esclarecermos que a autodeterminação é agora assegurada pelo consentimento ou dissentimento prospetivo, materialmente concretizado nas diretivas antecipadas de vontade, enquanto instrumento adequado à proteção dos direitos especiais da personalidade colocados em causa no campo de ação dos atos médicos, quando o outorgante se encontrar incapaz de facto.

Por conseguinte, há que convocar o recorte temporal entre a outorga da diretiva antecipada de vontade e o momento em que esta inicia a sua produção de efeitos. Falamos de consentimento ou dissentimento prospetivo quando o momento temporal se reporta à redação da diretiva antecipada de vontade - o outorgante estabelece neste momento orientações para o futuro, relativas a situações incertas, mais ou menos prováveis.

Por outro lado, estaremos já no plano da autonomia precedente quando o recorte temporal do momento da decisão se reportar ao evento no qual já se verifica a incapacidade de facto para consentir ou dissentir do paciente.

Nesse desiderato, ambas as modalidades de DAV respeitam ao recorte temporal da autonomia prospetiva, porquanto a autonomia precedente encerrará o momento em que aquelas já produzem efeitos, resultando que o consentimento ou dissentimento dependem do objeto da decisão a ser tomada, mediante a informação prestada e quadro clínico real.

Pretendendo realçar de início a importância das DAV, convocamos algumas situações reais, que não nos foram certamente indiferentes e que vivem, ainda que nas profundezas, da nossa memória.

Karen Ann Quinlan, de 21 anos de idade, em abril de 1975, deixou de ventilar, o que originou lesões cerebrais irreversíveis, ficando em estado vegetativo persistente durante 10 anos, com total ausência de funções cognitivas e dependência absoluta de suporte ventilatório. Faleceu em 1985. Viveu até 1975.

Nancy Beth Cruzan, em 1983, sofreu um grave acidente de automóvel, que a reconduziu ao estado vegetativo persistente, estado em que se manteve durante quase 8 anos. Ao contrário de Karen Quinlan, ventilava autonomamente. Contudo, dependia de alimentação e hidratação por via de tubo introduzido no seu corpo para o efeito, bem como não conseguia 
estabelecer qualquer tipo de comunicação com quem a rodeasse. Faleceu em 1990. Viveu até 1975.

Terri Schiavo, em estado vegetativo persistente durante 15 anos, alimentada e hidratada por meio de uma sonda, faleceu em 2005. Viveu até 1990.

Eluana Englaro permaneceu em estado vegetativo persistente desde 1992 até 2009 , data em que o Tribunal Italiano permitiu a retirada do suporte de alimentação artificial.

Cabe ainda recordar Ramón Sampedro, paraplégico desde 1968 até 1998, data em que foi encontrado morto. Ele invocava o direito a ser eutanasiado, o direito a libertar-se do corpo em que estava preso. Consideramos que a sua luta de 29 anos poderia ter sido evitada se as diretivas antecipadas de vontade estivessem legalizadas em 1968 no ordenamento jurídico espanhol e se Ramon tivesse expresso anteriormente a sua vontade, livre e esclarecida.

Julgamos que os casos agora chamados à colação poderiam ter sido evitados caso os "intervenientes" tivessem anteriormente manifestado as vontades respetivas por meio das diretivas antecipadas de vontade.

Devemos ressalvar que, quando utilizamos a expressão "Faleceu em... Viveu até...", o que pretendemos deixar claro é que a vida não pode apenas ser perspetivada enquanto biológica, mas deve, de igual forma, ser equacionada como biográfica.

Assim, a vida é um complexo de vida biográfica, ou seja, a vida "constituída pelas acções, decisões, motivos e acontecimentos que compõe o que agora chamamos biografia" e vida biológica. ${ }^{6}$

Esclarecendo a nossa posição, seguimos a orientação de James Rachel, defendendo que há de facto uma diferença entre viver e ter uma vida; o ser humano pode estar vivo na medida em o organismo cumpre as suas funções vitais (vida biológica), com suporte artificial ou sem ele, não obstante a vida biográfica, a vida de acordo com o projeto individual de cada um, pode já ter terminado. ${ }^{?}$

\section{A DOUTRINA DA ALTERNATIVA MENOS RESTRITIVA DE DI- REITOS}

A figura do procurador de cuidados de saúde teve origem no Direito norte-americano, datando de 1976, e corresponde ao springing durable power of attorney, cuja eficácia da representação só produz efeitos após a incapacitação do representado. ${ }^{8}$

Foi pensada como uma alternativa aos rígidos procedimentos judiciais de suprimento da vontade dos adultos com capacidade diminuída e enquadra-se na raiz na Doutrina da Alternativa Menos Restritiva de Direitos, que determina uma intervenção mínima no que respeita à restrição da liberdade dos adultos com capacidade diminuída. ${ }^{9}$ 
Esta era, também, a orientação propugnada pelo Conselho da Europa, que preconizava a adoção de mecanismos os menos restritivos possíveis. Assim, a Recomendação $\mathrm{N}^{0} 99 / 4^{10}$ apelava à necessidade de tomar em consideração as disposições tomadas antecipadamente pela pessoa incapacitada, em uma altura em que ainda seja plenamente capaz, apontando como exemplos desse tipo de instrumentos o mandato ${ }^{11}$ ou a procuração permanente.

O Princípio 3, sob a epígrafe "máxima preservação da capacidade", prescreve no $\mathrm{n}^{\circ} 2$ que as medidas de protecção não devem acarretar uma privação automática da faculdade de decisão do adulto incapaz em matérias pessoais, incluindo nestas, expressamente, o direito de voto, de fazer testamento e de tomar posição quanto a intervenções respeitantes à sua

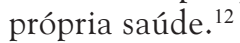

No mesmo sentido, a mais recente Recomendação 2009/11 - Relativa aos Princípios Respeitantes ao Procurador de Cuidados de Saúde e às Diretivas Antecipadas de Vontade, ${ }^{13}$ apelava para que os Estados-Membros introduzissem, ou atualizassem, as leis relativas a procuradores de cuidados de saúde e diretivas antecipadas de vontade. ${ }^{14}$

Considerando que a autonomia é o pruis crescente a ser prosseguido, designadamente, por meio do seu principal veículo, a expressão da vontade, tornou-se imperativo potenciar a autodecisão com caráter vinculativo, em detrimento de soluções heterónomas e paternalistas. ${ }^{15}$

No âmbito de uma sociedade laica e plural, as mais fundamentais decisões da vida de cada um devem ser tomadas pela própria pessoa que, concomitantemente, deve chamar a si a responsabilidade por tais decisões. Assim, a dignidade da pessoa humana é convocada para densificar o direito à autonomia da vontade, enquanto corolário do direito ao livre desenvolvimento da personalidade $\left(\mathrm{n}^{\mathrm{O}} 1\right.$ art. $^{\circ} 26$ da Constituição da República Portuguesa, doravante designada CRP), ${ }^{16}$ também ele ligado à integridade pessoal. ${ }^{17}$

Impôs-se, assim, criar instrumentos adequados a obviar as perplexidades resultantes da incapacidade de manifestar o consentimento ou dissentimento para ato médico, admitindo-se a qualquer sujeito que, antecipadamente e enquanto plenamente capaz, previsse uma futura situação de doença e incapacidade, escolhendo a forma de resolver a situação suscitada. ${ }^{18}$

Um dos mecanismos previstos para desempenhar essa função é a nomeação de um procurador de cuidados de saúde atendendo às suas virtualidades e ao caráter simples e flexível.

Trata-se de reconhecer uma autonomia inerente aos adultos incapazes de facto, de organização da própria vida, com o efeito performativo de possibilitar, na sua esfera jurídica pessoal, o exercício de autorrealização da personalidade. 


\section{DA DIGNIDADE DA PESSOA HUMANA E DA AUTODETERMI- NAÇÃO}

Quando falamos em Diretivas Antecipadas de Vontade - seja sob a forma de testamento vital, seja de nomeação de um procurador de cuidados de saúde - falamos no respeito pela dignidade da pessoa humana e na faceta da personalidade humana que é a autodeterminação prospetiva da pessoa. ${ }^{19}$ Falamos, assim, de uma conceção de dignidade da pessoa humana fundada na pessoa enquanto ser capaz de se autodeterminar.

De facto, do reconhecimento da dignidade da pessoa humana decorre, também, o reconhecimento do poder de a pessoa se autodeterminar, de dispor livremente das possibilidades de autoconformação da sua vida, incluindo aí o poder de se vincular ao não exercício ou invocação de uma posição de direito fundamental..$^{20}$

A dignidade da pessoa humana é um conceito aberto, concretizado em várias normas, por isso suscetível de diversas interpretações, contudo encerra uma dimensão geral de que a pessoa é colocada como fim último. Com Rui Nunes, "a dignidade confere-lhe o direito de ser sempre considerado como sujeito, em si mesmo, com uma finalidade própria". ${ }^{21}$

Enquanto conceito dotado de um elevado grau de abstração e generalidade, o princípio da dignidade da pessoa humana tem sido objeto de várias interpretações que, de acordo com Vera Lúcia Raposo, podem reduzir-se a duas grandes conceções: a dignidade como proteção do indivíduo, tradicional da cultura jurídica norte-americana; e a dignidade como autonomia do indivíduo, tradicional da cultura jurídica europeia. ${ }^{22}$

Da segunda conceção, podemos assacar o resultado de que o conceito de dignidade deve ser interpretado em harmonia com o direito ao livre desenvolvimento da personalidade, em virtude da proteção constitucional que lhe foi conferida.

Com o reconhecimento constitucional de um direito ao livre desenvolvimento da personalidade, procura-se deixar consagrado um direito à liberdade do indivíduo em relação aos modelos de personalidade, que integra um direito à diferença e que permite a cada um eleger o seu modo de vida desde que não cause prejuízo a terceiros. ${ }^{23}$

Com efeito, Stela Barbas esclarece que "a pessoa é um ser dotado de liberdade, ou é de per si liberdade; goza de autonomia, autodetermina-se, é um ser racional e autónomo". ${ }^{24}$

Na esteira de Rui Nunes, podemos ainda afirmar que a riqueza do paradigma do livre desenvolvimento e expressão da personalidade humana reside na diversidade individual de autodeterminação. Assim, no desenvolvimento da personalidade da cada pessoa, individualmente considerada, revela-se o poder de autodeterminação do seu titular. ${ }^{25}$ 
As diretivas antecipadas de vontade revelam, assim, a consagração do direito ao consentimento/dissentimento informado antecipado, em virtude da regra de que todas as intervenções médicas têm por base o consentimento informado, livre e esclarecido, ${ }^{26}$ pois trata-se aqui de uma intromissão terceira em uma zona de domínio e reserva da pessoa, que é o seu próprio corpo.

Já antes da regulação expressa da Lei $\mathrm{N}^{\mathrm{o}}$ 25/2012, de 16 de julho, a conceção de autonomia prospetiva em si mesma não podia receber o repúdio do ordenamento jurídico interno.

Nesse sentido, no contexto europeu, o art. $9^{\circ}$ da Convenção Europeia sobre os Direitos do Homem e da Biomedicina (doravante designada CDHB) propugnava já expressamente a valorização da vontade anteriormente manifestada, ${ }^{27}$ sendo que essa Convenção é um instrumento internacional de caráter vinculativo para os países que a ratificaram e foi acolhida na ordem jurídica portuguesa no momento da sua ratificação, em 3 de janeiro de 2001.28

No plano interno, o bem jurídico protegido pelo tipo do art. 156 do Código Penal (doravante designado $\mathrm{CP})^{29}$ não é a vida nem a saúde do paciente, mas sim a sua autodeterminação, enquanto liberdade de dispor sobre a vida e sobre o corpo, o que implica que, pese embora o princípio in dubio pro vita seja o princípio norteador do sistema penal que preside à atuação médica, ${ }^{30}$ o legislador tenha admitido que o direito à autodeterminação prevaleça, inclusivamente, sobre o direito à vida e à própria integridade física em determinadas circunstâncias. ${ }^{31}$

Por isso, a recusa de tratamento não pode ser considerada suicídio, nem mesmo quando daí resulte a morte, e, consequentemente, a supressão da esfera jurídica do titular dos bens da personalidade em causa (e de onde emanou a declaração de vontade), pois trata-se apenas de uma afirmação do direito fundamental à autodeterminação sobre matérias relativas ao corpo, à saúde e à vida, o qual resulta do direito ao livre desenvolvimento da personalidade $\left(\mathrm{n}^{\mathrm{O}}\right.$ 1 do art. 26, CRP)..$^{32}$

O direito à vida é um direito logicamente essencial e prioritário à existência da pessoa e é condição de todos os outros direitos fundamentais. Todavia, o direito à vida não é integrado por um dever de viver, pois não existe um dever de proteção da vida pelo seu titular e, em bom rigor, é na sua essência um direito da pessoa sobre si mesma. "Num sentido normativo, o direito à vida significa primeiro e acima de tudo, direito de não ser morto, de não ser privado da vida." ${ }^{34}$

A pessoa tem direito a realizar a sua vontade de forma autônoma e livre, decidindo a sua própria vida, e a ordem pública apenas intervirá no caso de se sentir afetada - nesse sentido, uma eventual recusa não deixará de respeitar o âmbito do $\mathrm{n}^{\mathrm{o}} 1$ do art. $81^{35}$ e art. $340^{36}$ do CC.

Os artigos $156^{\circ}$ e $157^{\circ}$ do Código Penal, precisamente sobre intervenções e tratamentos médico-cirúrgicos arbitrários, procuram em qualquer caso, "definir um equilíbrio (necessariamente instável e precário) entre direitos tão fundamentais como de um lado, $a$ 
liberdade e a autodeterminação pessoal, um dos «nomes» da própria dignidade pessoal; do outro lado, a integridade física, a saúde e [em casos extremos] a vida, afinal de contas o pressuposto existencial da dignidade". ${ }^{37}$

Entendemos que o aparente conflito entre a dignidade da pessoa humana e a autodeterminação, que determina a prevalência daquela primeira, é apenas residual e motivado por um raciocínio que faz coincidir a dignidade humana com a vida humana. ${ }^{38}$ Com efeito, basta atender à tipicidade da norma penal incriminadora, ainda que a recusa se faça contra a vida, para que se evidencie a fragmentaridade da norma, deixada pelo legislador na livre disponibilidade do seu titular.

É porque a pessoa é ela própria um poder de autodeterminação que tem o poder de exigir o respeito de si própria como sede conformadora desse poder, e, nesse sentido, convocamos o desenvolvimento do tema para a Teoria Geral do Direito Civil, tendo presente que o Direito Civil é a zona de igualdade jurídica e do reconhecimento, pelo sistema do direito objetivo, do valor eminente da pessoa tout court. ${ }^{39}$

Ora, para que cada um seja verdadeiramente pessoa, é necessário garantir-lhe condições essenciais ao seu ser e devir e, portanto, ao livre desenvolvimento da personalidade, consagrado no $\mathrm{n}^{\mathrm{o}} 1$ do art. 26 da CRP: essas condições são os direitos de personalidade, enquanto mecanismos operativos dos próprios direitos fundamentais.

A consagração legal da representação voluntária em matéria de cuidados de saúde, veiculada pela nomeação de um procurador de cuidados de saúde, verificada a incapacidade de facto de consentir ou recusar do paciente, consubstancia uma manifestação da dignidade da pessoa humana, titular inelutável de direitos fundamentais, reconhecidos e protegidos pelo Estado de Direito Democrático.

Com efeito, é esse conceito pluridimensional que convoca ao ordenamento jurídico a necessidade de reconhecer o espaço de liberdade, planeamento e conformação da pessoa em relação à sua própria vida e que impõe, com garantia jurídica, que à própria pessoa deva ser assegurada uma área de autodeterminação, ${ }^{40}$ concordantemente prática com medidas privadas de proteção da sua vontade: trata-se, nesse sentido, de uma dimensão objetiva do direito à autodeterminação em cuidados de saúde.

\section{O DIREITO SUBJETIVO DE PERSONALIDADE}

A principal regulamentação jurídica dos direitos de personalidade encontra-se nos art.70 a 81 do CC, e, nessas disposições, o Direito protege a personalidade, recorrendo ao direito subjetivo.

Neste, concebe-se o direito subjetivo substancialmente como uma posição jurídica vantajosa e dominantemente ativa, inerente ao aproveitamento jurídico 
de um bem que integra, e da qual emergem poderes e vinculações necessários ao êxito desse aproveitamento: o fim que o direito subjetivo de personalidade visa a proteger é a dignidade do seu titular. ${ }^{41}$

Se quisermos, e em uma outra conceção de direito subjetivo, tratam-se de direitos da pessoa sobre a própria pessoa, verdadeiros iura in se ipsum, em que a pessoa é simultaneamente sujeito de direitos e objeto desses mesmos direitos.

Com efeito, os direitos de personalidade são um mecanismo jurídico de proteção das pessoas enquanto pessoas, reconhecem poderes e protegem bens pessoais, elementos concretos da pessoa. ${ }^{42}$ Nesse sentido, são em simultâneo instrumento da autonomia pessoal e mecanismo de tutela dessa autonomia.

As declarações de vontade, que exprimem o consentimento ou dissentimento para intervenções médicas, referem-se a bens jurídicos da personalidade com dignidade constitucional - vida e integridade física e psíquica - que se encontram sob a tutela da cláusula geral do art.70 do CC. ${ }^{43}$

Em virtude do caráter pessoalíssimo dos bens envolvidos, a doutrina tem defendido a intransmissibilidade dos poderes sobre a personalidade física e psíquica, pelo que não se poderia admitir a representação voluntária, pois esta teria por referência a prática de negócios jurídicos em representação, argumentando que tal equivaleria a entregar a um terceiro o direito subjetivo que abrange esse bem, exigindo-se, por isso, que o direito seja sempre exercido pelo seu titular. ${ }^{44}$

Por conseguinte, a regra norteadora do hodierno Direito médico português, acolhida pelo art. 156 do CP, que consagra o reconhecimento do consentimento ou dissentimento como pedra de toque da relação médico-paciente, é de que todas as intervenções médicas têm por base o consentimento informado.

Nesse contexto, o médico só pode atuar mediante prévio consentimento do paciente, o qual deve ser livre e informado, nos termos do art. $157^{45}$ do CP e $\mathrm{n}^{\mathrm{o}} 1$ do art. $^{\circ} 45^{46}$ do Código Deontológico da Ordem dos Médicos (doravante designado $\mathrm{CDOM}$ ), pelo que conforma de per si uma lege artis da prática médica. ${ }^{47}$

Exceção a essa regra é apenas o privilégio terapêutico, convocado sempre que as informações possam causar dano ao paciente, também previsto na parte final do artigo 157 do CP, cuja epígrafe é precisamente "Dever de esclarecimento".

Ora, se para o caso de um doente adulto e plenamente capaz, a regra do $\mathrm{n}^{\mathrm{O}} 1$ do art. 156 do CP é clara e a decisão quantos aos cuidados de saúde que deseja, ou não, receber cabe-lhe exclusivamente, o mesmo não se verifica quando determinadas circunstâncias tornam os indivíduos incapazes de manifestar decisões por si formadas, sendo que, nesses casos, é necessário o recurso ao consentimento presumido. ${ }^{48}$

O consentimento presumido funda-se na vontade hipotética do paciente (critério subjetivo) e não na consideração do que seja o maior bem para o paciente (critério objetivo). Tratando-se de doentes sem prévia manifestação 
de vontade, a resolução do caso dependerá do consentimento presumido, avaliado pelo médico e, caso este não possa ser apurado com rigor, daquilo que ele próprio entenda como sendo o mais correto em face às leges artis e ao princípio da beneficência na situação suscitada. ${ }^{49}$

Assim, se a decisão compete apenas ao paciente, ou à forma como o médico presuma o consentimento deste, em virtude de o consentimento ser um ato meramente pessoal e incidir sobre o núcleo da personalidade física e psíquica da pessoa, a única exceção legalmente reconhecida a essa regra é, agora, a existência de um procurador de cuidados de saúde.

Colocou-se, assim, o problema específico de saber, nos termos do Direito constituído português, por que forma se admitia a representação voluntária em matéria de consentimento ou dissentimento para a realização de tratamentos e intervenções médico-cirúrgicas, estando aqui em causa direitos de personalidade - designadamente a vida, a integridade física e psíquica - que são de exercício pessoal e intransmissíveis. ${ }^{50}$

Esse princípio deve sofrer limitações em casos excepcionais, nos quais a pessoa não consegue realmente se beneficiar desses bens, sendo necessário que outrem exerça um poder sobre bens da personalidade alheios no interesse do respectivo titular, ${ }^{51}$ como sucede, a título de exemplo, no caso específico de incapacidade de manifestação do consentimento ou recusa de uma intervenção médica.

O direito subjetivo de personalidade tem como fim a realização, o respeito e a proteção da dignidade humana do seu titular e tem como meios uma pluralidade de poderes de diversa ordem que são adequados a assegurar o êxito na realização daquele fim: os direitos de personalidade são, em simultâneo, instrumento da autonomia pessoal e mecanismo de tutela dessa autonomia, como já referimos. ${ }^{52}$

Assim, o resultado de uma limitação voluntária de um direito de personalidade não pode nunca consistir em uma perda, ainda que parcial, desse direito por parte da pessoa em causa. O poder sobre os bens da personalidade apenas pode pertencer à pessoa a que esses bens estão integrados, o que, bem assim, determina que o correspondente exercício se encontre reservado ao seu titular. ${ }^{53}$

Em bom rigor, por uma pessoa ter limitado um direito de personalidade, esse direito não deixa de ter os poderes e as demais posições ativas que tinha anteriormente e que o integram inelutavelmente. A limitação dos direitos de personalidade incide sobre os meios de tutela, defesa ou garantia. $\mathrm{O}$ titular do direito de personalidade limita voluntariamente os meios de tutela de modo a que não reajam em face de uma intervenção do terceiro sobre o bem da personalidade abrangido. ${ }^{54}$

\section{PROCURADOR DE CUIDADOS DE SAÚDE}

Resulta do $\mathrm{n}^{\mathrm{O}} 1$ do art. 11 da Lei Reguladora das Diretivas Antecipadas de Vontade (doravante designada LDAV) que o procurador de cuidados de saúde é o representante escolhido pelo paciente, em um momento em que se 
encontra na posse das suas capacidades intelectuais e volitivas, para que, na eventualidade de se encontrar incapaz de tomar decisões, este tome as, ou apenas determinadas, decisões necessárias para prover à sua saúde. ${ }^{55} 5657$

A decisão do PCS é vinculativa, ${ }^{58}$ pois atua em nome e por causa do paciente com base em um mandato expresso que aquele lhe outorgou, e, portanto, tem o mesmo valor que a vontade manifestada pelo próprio paciente, ${ }^{59}$ caso se encontrasse competente para consentir.

A nomeação de um procurador de cuidados de saúde surge, assim, como uma resposta a uma incapacidade específica limitada à área da saúde e emerge como um meio de suprimento da incapacidade para prestar consentimento ou dissentimento para ato médico, que pensamos ser o pódio do regime em referência.

Como refere Rui Nunes:

apesar de o Testamento Vital ser o corolário natural de uma trajectória de reforço do direito à autodeterminação da pessoa, convém referir também alguns dos seus limites e insuficiências. Desde logo a dificuldade em traduzir a complexidade de muitas situações clínicas em palavras, que posteriormente serão plasmadas num documento com valor jurídico. Daí que apesar de surgirem inúmeras tentativas de discriminar os actos médicos passíveis de consentimento ou dissentimento prospectivo - através da elaboração de directivas médicas circunstanciadas - a generalidade das legislações aprovadas neste domínio opta por formulários simples, com expressões genéricas, em que mais do que caracterizar os actos médicos específicos se dá uma indicação clara dos valores éticos a respeitar. ${ }^{60}$

A atuação sobre bens da personalidade alheios apenas deve resultar de mecanismos jurídicos que não impliquem a integração desse bem na esfera jurídica de terceiro. Portanto, o que poderá fazer o representante é agir sobre esse mesmo bem, mas sempre com base em figuras jurídicas que, embora pesem, consigam servir de suporte a essa atuação, não causem domínio sobre esse bem. ${ }^{61}$

Ora, partindo da premissa de que a nomeação de um PCS não implica a transferência de direitos de personalidade, em virtude de estes não se poderem transmitir porque são inerentes à própria pessoa e insuscetíveis de dela se separarem, qualquer negócio que operasse essa transmissão seria, ab inito, contrário à lei e à ordem pública, nos termos do art. 81 e do art. 280, CC, desenvolvemos o nosso raciocínio.

Contudo, a doutrina mais tradicional aduzia tese contrária, alegando que o procurador estaria a substituir ao paciente na decisão do curso da sua vida, do seu corpo e da sua personalidade, decidindo, por vezes, até a sua morte, sendo certo que tal equivaleria a entregar a um terceiro o direito subjetivo que abrange esses bens.

Na verdade, o que se transmite, sim, é o seu exercício, e isso já se admite por meio do recurso à analogia com o instituto da representação voluntária. 
Entendemos, assim, que a procuração outorgada em matéria de cuidados de saúde, no interesse exclusivo do dominus nos termos do $\mathrm{n}^{\mathrm{o}} 2$ do art. 265 do CC, ${ }^{62}$ encontrava já acolhimento por força do princípio da unidade do ordenamento jurídico, e vários argumentos advogam nesse sentido.

\section{DESFUNCIONALIZAÇÃO DO PRINCÍPIO DA INSTRANSMISSI- BILIDADE DOS DIREITOS DE PERSONALIDADE}

Em sede de Teoria Geral do Direito Civil há representação, em geral, e no estritos termos do $\mathrm{n}^{\mathrm{o}} 2$ do art. ${ }^{\mathrm{o}} 265$ do $\mathrm{CC},{ }^{63}$ quando uma pessoa pode fundadamente agir em nome e no interesse de outrem ${ }^{64} \mathrm{e}$ estes três elementos são observáveis na representação em matéria de cuidados de saúde.

A atuação no interesse de outrem impõe ao representante a prossecução de interesses alheios - do representado - e não próprios. Nesse contexto, atuando o representante no interesse de outrem, na verdade, ele está investido de poderes-funcionais e não de verdadeiros direitos subjetivos.

Ora, o poder funcional demarca-se dos direitos subjetivos stricto sensu por nele se verificar a dissociação entre a titularidade do poder, que cabe a certa pessoa, e a titularidade do interesse, de outrem, por meio dele prosseguido, ${ }^{65}$ ou seja, o representante serve-se do seu poder jurídico apenas na prossecução da realização do interesse do representado, no caso, de acordo com o critério dos melhores desejos do paciente, recorrendo-se ao julgamento substitutivo.

Atendendo, ainda, à regulamentação legal da procuração, parece, em primeira análise, que esse instrumento apenas serviria para conceder poderes representativos para a prática de negócios jurídicos, e, em bom rigor, esta é a interpretação que resulta do $\mathrm{n}^{0} 2$ do art. 262 do CC $^{66}$, que define a forma da procuração com referência ao negócio jurídico a celebrar em representação.

Em matéria de cuidados de saúde, encontraremos o procurador de cuidados de saúde, muitas vezes, a celebrar atos que são pacificamente considerados negócios jurídicos (v.g. contratar profissionais de saúde, autorizar o ingresso em hospitais). Todavia, o ato que enformará a mais importante incumbência do procurador de cuidados de saúde é o consentimento ou dissentimento médico. Ora, o consentimento médico não é unanimemente considerado um negócio jurídico. ${ }^{67}$

Na verdade, o consentimento deverá ser caraterizado como um simples ato jurídico, pessoal e de natureza formal, manifestado por uma vontade expressa, que, por força e relevância da vontade expressa, integra a categoria dos quase negócios jurídicos, pois os efeitos resultam ex lege, não relevando autonomamente a vontade quanto à produção dos mesmos. ${ }^{68}$

Por conseguinte, o regime jurídico aplicável em sede de consentimento será o resultante da norma remissiva do art. 295 do CC, ${ }^{69}$ que determina a aplicação aos atos jurídicos, que não são negócios jurídicos, das disposições precedentes relativas aos negócios jurídicos, sempre que a analogia das si- 
tuações o justifique, e, no caso concreto, observando o regime especialmente regulado na $\mathrm{LDAV} .^{70}$

Nessa perspectiva, o problema do objeto da representação em matéria de cuidados de saúde - consentimento ou dissentimento - e o problema de o instituto da representação voluntária se referir apenas a negócios jurídicos encontrar-se-ia resolvido, também, por via da analogia.

Contudo, a posicionar-se de forma cabal relativamente à matéria da representação voluntária concernente a problemas da personalidade, verificamos que a tese do princípio da intransmissibilidade dos direitos de personalidade se revelava contraditória com a aceitação do regime da representação legal em matéria de direitos de personalidade no âmbito das incapacidades jurídicas, ou seja, a interdição e a inabilitação, cujos meios de suprimento são a tutela e a curatela respetivamente.

A nomeação do procurador de cuidados de saúde visa à proteção da pessoa incapaz, tal como as medidas de proteção instituídas no âmbito das incapacidades jurídicas. ${ }^{71}$ Por conseguinte, entendemos que, embora o âmbito da representação legal se encontrasse já definido, como fenômeno de substituição de vontades que tem por fonte a lei e uma sentença judicial, e o mesmo não se verificasse para a representação voluntária em matéria de cuidados de saúde, a lógica subjacente que preside a ambos os institutos é a mesma.

Acresce que as medidas de proteção no âmbito das incapacidades jurídicas foram desenhadas obedecendo ao modelo tradicional de proteção do património do incapaz, pretendendo se assegurar a sua participação no tráfego jurídico. ${ }^{72}$

Ora, a nomeação de um procurador de cuidados de saúde garante o respeito da vontade da pessoa incapaz em matéria de cuidados de saúde, mesmo quando foi instaurada uma medida de proteção, o que implica que, mesmo que se verifique em simultâneo um representante legal e um representante voluntário e que os dois instrumentos coincidam na mesma pessoa, o padrão de atuação do procurador de cuidados de saúde deverá pautar-se pelo critério dos melhores desejos do paciente, e não o dos melhores interesses, que se identifica mais facilmente com o critério da diligência do bom pai de família previsto no art. 1935 do CC. ${ }^{73}$

Ora, um representante legal pode tomar decisões médicas (art. 145, CC), ${ }^{74}$ mas não pode, por exemplo, casar a pessoa incapacitada. A pessoa incapacitada judicialmente, designadamente no caso da interdição, não tem sequer capacidade de gozo desses direitos - alínea b, art. 1601, CC e alínea b, art. 2189, CC.

A ordem de razão aqui subjacente é, assim, a de que decisões médicas têm de ser tomadas para a proteção dos bens essenciais da personalidade, e, assim, admitia-se a substituição de vontades relativamente a problemas da personalidade no âmbito da representação legal.

Contudo, há de realizar uma distinção dentro da categoria dos atos meramente pessoais. Com efeito, certos atos (v.g. casar, perfilhar ou testar) não 
são decisões necessárias, no sentido em que terão de ser tomadas sob pena de deixarem desprotegida a vida, a saúde ou a integridade física da pessoa incapaz, ${ }^{75}$ e, portanto, não é necessário que um terceiro (representante) intervenha, por isso mesmo não custa compreender que um dever específico do tutor seja o de cuidar especialmente da saúde do interdito, nos termos do art.145, CC.

Todavia, daqui resulta mais um argumento. O Direito vigente em Portugal admitia o recurso à procuração para efeitos de celebração de casamento (art.1620, CC) ${ }^{76}$ e de perfilhação (art.1849, CC) ${ }^{77}$ também atos pessoais e livres, pelo que, em bom rigor, entendemos que não havia justificação para não o admitir em matéria de cuidados de saúde. ${ }^{78}$

Acresce que não se compreende, e tornaria tautológica a unidade do sistema jurídico, que existissem normas como a da alínea b do $\mathrm{n}^{\mathrm{o}} 1$ do art. 143 do $\mathrm{CC}^{79}$, que consagram a possibilidade de os pais, ou o progenitor que exerce o poder paternal, designarem o futuro representante da pessoa a incapacitar e não se admitisse esse tipo de escolha por parte do próprio representado.

\section{CONCLUSÕES}

Beneficiando do contributo dogmático da Teoria Geral do Direito Civil, há representação, em geral, quando uma pessoa pode fundadamente agir em nome e no interesse de outrem, e deste resultam os três elementos do conceito de representação: atuação em nome de outrem, atuação no interesse de outrem e poder representativo.

Ora, se o representante prossegue interesses alheios - do representado - e não próprios, na verdade, ele está investido de poderes-funcionais e não de verdadeiros direitos subjetivos, e, assim, o representante serve-se do seu poder jurídico apenas na prossecução da realização do interesse do representado.

O terceiro elemento do conceito (legitimidade indireta) implica a necessidade de ao representante serem atribuídos poderes representativos, uma vez que neles se fundam a legitimidade da intervenção do terceiro em esfera jurídica alheia.

Tratando-se de uma área tão específica como a saúde, aplicar-se-á a regra geral que vale para as procurações outorgadas no âmbito da representação em negócios jurídicos, admitindo-se, por isso, que o outorgante defina limites e condições de atuação ao procurador de cuidados de saúde - trata-se, aqui, de salvaguardar a proteção da vontade, da autonomia e do interesse do dominus.

Essa salvaguarda deverá operar-se ao nível do conteúdo da procuração, ou seja, aos poderes do procurador de cuidados de saúde, e à definição, ou não, de limites à vontade manifestada pelo procurador de cuidados de saúde.

Esta era, aliás, a orientação da Associação Portuguesa de Bioética, que já havia destacado a importância de que o conteúdo da procuração fosse preciso, claro e inequívoco, delimitando com exatidão os poderes que competem ao 
procurador e a cujo exercício corresponderá a produção de efeitos jurídicos na esfera do paciente. ${ }^{80}$

Pretende-se assegurar que o procurador de cuidados de saúde prossegue o interesse do outorgante em matéria de cuidados de saúde, além disso, a preservação residual da autonomia do paciente incapaz de facto, e não reduzir a figura do procurador à condição de mero núncio.

Pelo contrário, pois, atendendo às virtualidades da figura do procurador de cuidados de saúde, a sua nomeação acaba permitindo uma decisão casuística, uma vez que decide contemporaneamente ao surgimento da necessidade do ato médico, bem como tem acesso à informação atualizada sobre o estado do paciente e sobre as terapêuticas possíveis, pelo que poderá tomar decisões mais conformes com o próprio conceito de consentimento informado. ${ }^{81}$

Trata-se de um instrumento flexível, que permite uma atuação em qualquer estado de doença, facultando a possibilidade de se modelar a manifestação de vontade delegada a objetivos muito específicos.

A figura do procurador de cuidados de saúde enquadra-se numa trajectória de reforço da autonomia da pessoa sendo outro instrumento de defesa dos direitos inalienáveis dos doentes. Ou seja, espera-se que a decisão seja tomada com base no quadro de valores da pessoa doente, e só quando este referencial axiológico é desconhecido é que aplica o critério genérico do melhor interesse do paciente. ${ }^{82}$

Beneficiando, aqui, mais uma vez da dogmática da Teoria Geral do Direito Civil, a figura da representação exige a atribuição ao representante de um mínimo de poder de decisão, ainda que este coexista com instruções do representado, às quais aquele deve obedecer escrupulosamente.

Como refere João Loureiro, representar é

uma forma de exercício da autonomia pelo cidadão, que não será posta em causa se observados certos requisitos, proibindo-se que se passe um cheque em branco, de forma a obstar que a decisão seja entendida como uma decisão do representante, sem qualquer referência às orientações do representado. ${ }^{83}$

Por isso, entendemos que esses poderes devem ser atribuídos de forma mais concreta e pormenorizada uma vez que, se a procuração for pouco detalhada, poderá ser requerido ao Tribunal que intervenha e se substitua ao procurador de cuidados de saúde, caso despontem motivos sólidos para entender que aquela não seria a vontade do paciente.

Na verdade, não existindo manifestação antecipada de vontade na forma de testamento vital, ou existindo dúvidas quanto ao seu conteúdo, o procedimento seria o de apurar a vontade presumida, leia-se, recorrer ao consentimento presumido, pois resulta claro que uma apreciação judicial não se compadece com situações de urgência. 
O recurso ao consentimento presumido apenas é admitido quando o paciente se encontra inconsciente ou, por qualquer outra razão, incapaz de consentir a intervenção médica, sendo esta absolutamente inadiável, e, também agora, afastando a decisão do procurador de cuidados de saúde. ${ }^{84}$

Ora, nesse caso, e pretendendo-se com as diretivas antecipadas de vontade, concomitantemente, afastar o recurso ao consentimento presumido, será mais proficiente que esta seja manifestada por alguém escolhido em momento anterior, livremente e conscientemente, pelo "agora" paciente incapaz de expressar autonomamente a sua vontade, do que a própria lei, pois nele reside o juízo respeitante à pessoa competente para conhecer a sua vontade - assim, entendemos que uma salvaguarda cabal da vontade do adulto com capacidade diminuída se opera da definição do conteúdo claro e preciso de instruções do representado.

Esse representante não tem de ser um familiar, porém, mesmo que o seja, há uma grande diferença entre o papel da pessoa quando é ouvida na pura vertente de familiar e quando é ouvida na qualidade de PCS, pois, no primeiro caso, a sua opinião é tida em conta como mero indício de qual seria a vontade do paciente (consentimento presumido $\mathrm{n}^{\mathrm{O}} 2$ do art. 156 do $\mathrm{CP}$ ), logo, não é vinculativa; ao passo que, no segundo caso, como PCS, a sua decisão é vinculativa, pois atua em nome e por conta do paciente com base em um mandado expresso que aquele the concedeu, ou seja, tem o mesmo valor que a vontade manifestada pelo próprio paciente. As decisões do PCS, dentro dos limites da procuração que lhe foi concedida, prevalecem sobre as de qualquer outra pessoa, exceto as do próprio outorgante..$^{85}$

A admissão da representação voluntária em matéria de cuidados de saúde, por meio da nomeação de um procurador de cuidados de saúde, assegura, na verdade, essa faceta da personalidade humana que é a autodeterminação prospetiva, não colocando em causa sequer o princípio da unidade do ordenamento jurídico, uma vez que o contrário apenas poderá resultar de uma conceção tendencialmente absoluta da intransmissibilidade dos direitos de personalidade. ${ }^{86}$

Em bom rigor, na maioria das vezes, o âmbito da decisão implicará o direito a morrer de uma forma digna, mas, por outro lado, poderá permitir uma intervenção terapêutica que, com toda a probabilidade, venha a possibilitar o desenvolvimento do projeto de vida do representado de acordo com os seus valores pessoais e com qualidade. ${ }^{87}$

A nomeação de um procurador de cuidados de saúde é um profícuo mecanismo de salvaguarda do cumprimento da vontade do representado e da sua autodeterminação prospetiva: é uma manifestação da autonomia pessoal, e, embora a decisão não seja tomada pelo próprio paciente, apresenta-se como um reforço da autonomia da pessoa, sendo outro instrumento de defesa dos direitos inalienáveis dos doentes. Assim, o reconhecimento legal desse exercício delegado era eminente e impunha-se em um domínio tão proeminente como os cuidados de saúde. 
Concluindo, julgamos que cumpridos certos requisitos substanciais, designadamente quanto ao conteúdo dos poderes representativos, essa vertente da representação voluntária concernente aos tratamentos e às intervenções médico-cirúrgicas era já admissível nos termos do Direito constituído no ordenamento jurídico português, permitindo-se a autodeterminação prospetiva e a representação do exercício de direitos de personalidade.

\section{REFERÊNCIAS}

ASSOCIAÇÃO PORTUGUESA DE BIOÉTICA. Parecer n⿳0 P/05/APB/06 sobre as directivas antecipadas de vontade. Disponível em: <http://www. apbioetica.org/fotos/gca/12802556471148471346directivas_medicas_parec er_05.pdf >. Acesso em: 29 jul. 2016.

BARBAS, Stela Marcos de Almeida Neves. Direito do genoma humano. Coimbra: Edições Almedina, 2007.

CANOTILHO, Gomes; VITAL, Moreira. Constituição da República Portuguesa: artigos $1^{\circ}$ a $107^{\circ}$. Coimbra: Coimbra Editora, 2014.

CARVAlHO, Orlando de. Teoria Geral do Direito Civil. 3. ed. Coimbra: Coimbra Editora, 2012.

CONSELHO DA EUROPA. Convenção para a Protecção dos Direitos do Homem e da Dignidade do ser Humano face às Aplicações da Biologia e da Medicina: Convenção sobre os Direitos do Homem e da Biomedicina. Disponível em: < http://www.gddc.pt/direitos-humanos/textosinternacionais-dh/ tidhregionais/convbiologiaNOVO.html>. Acesso em: 27 jul. 2016.

COUNCIL OF EUROPE. Recommendation CM/REC (2009) 11 of the Committee of Ministers to Member States on Principles Concerning Continuing Powers of Attorney and Advanced Directives for Incapacity. Disponível em: $<$ https://wcd.coe.int/ViewDoc.jsp?id=1563397\&Site=CM>. Acesso em: 30 jul. 2016.

COUNCIL OF EUROPE. Recommendation $n^{\circ} \mathrm{R}(99) 4$ of the Commitee of Ministers to Member States on Principles Concerning the Legal Protection of Incapable Adults. Disponível em: < http://www.coe.int/t/dg3/healthbioethic/ texts_and_documents/Rec(99)4E.pdf>. Acesso em: 30 jul. 2016.

FERNANDES, Luís Alberto Carvalho. Teoria Geral do Direito Civil: introdução e pressupostos da relação jurídica. 4. ed. Lisboa: Universidade Católica Editora, 2007. v. 1.

FERNANDES, Luís Alberto Carvalho. Teoria Geral do Direito Civil: fontes, conteúdo e garantia da relação jurídica. 4. ed. Lisboa: Universidade Católica Editora, 2007. v. 2. 
LOUREIRO, João Gonçalves. Metáfora do vegetal ou metáfora do pessoal? considerações jurídicas em torno do estado vegetativo crónico. Cadernos de Bio-Ética, Coimbra, n. 8, p. 27-65, dez. 1994.

MIRANDA, Jorge; MEDEIROS, Rui. Constituição Portuguesa Anotada, tomo i, artigos $1^{\circ}$ a $79^{\circ}$. Coimbra: Coimbra Editora, 2005.

NOVAIS, Jorge Reis. Renúncia a direitos fundamentais. In: MIRANDA, Jorge (Org.). Perspectivas constitucionais nos 20 anos da Constituição de 1976. Coimbra: Coimbra Editora, 1996. v. 1. p. 263-335

NUNES, Rui. Consentimento informado e boa prática clínica. Julgar, Lisboa, número especial, p. 115-138, 2014.

NUNES, Rui; MELO, Helena Pereira de. Testamento vital. Coimbra: Edições Almedina, 2011.

OLIVEIRA, Nuno. O princípio da dignidade da pessoa humana e a regulação jurídica da bioética. Revista Portuguesa de Direito da Saúde, Coimbra, ano 8, n. 15, p. 29-33, jan./jun. 2011.

ORDEM DOS MÉDICOS. Código deontológico da ordem dos médicos. Disponível em: <https:/www.ordemdosmedicos.pt/?lop = conteudo\&op=9c838d 2e45b2ad1094d42f4ef36 764f6\&id =cc42acc8ce334185e0193753adb6cb77>. Acesso em: 28 jul. 2016.

PEREIRA, André Dias. Diretivas antecipadas de vontade em Portugal. Julgar, Lisboa, número especial, p. 287-304, jul. 2014.

PEREIRA, André Gonçalo Dias. O consentimento médico informado na relação médico-paciente. Coimbra: Coimbra Editora, 2004.

PINHEIRO, Jorge Duarte. As pessoas com deficiência como sujeitos de direitos e deveres: incapacidades e suprimento. Lisboa: Faculdade de Direito da Universidade de Lisboa, 2009. Disponível em: <http:/www.icjp.pt/sites/ default/files/media/600-886.pdf>. Acesso: 1 ago. 2016.

PORTUGAL. Associação Portuguesa de Bioética. Estudo no E/17/APB/10 - Testamento vital. Realtor: Rui Nunes. Porto, 18 set. 2010. Disponível em: <http://www.apbioetica.org/fotos/gca/1284923005parecer-testamento_vital. pdf $>$. Acesso em: 4 ago. 2016.

PORTUGAL. Procuradoria Geral Distrito de Lisboa. Código Civil. Disponível em: <http://www.pgdlisboa.pt/leis/lei_mostra_articulado. php?artigo_id $=775$ A0070\&nid $=775 \&$ tabela $=$ leis \&pagina $=\overline{1} \&$ ficha $=1 \&$ 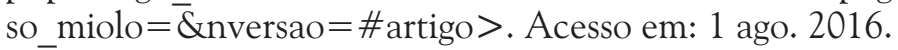

PORTUGAL. Procuradoria Geral Distrito de Lisboa. Código Penal. Disponível em: <http://www.pgdlisboa.pt/leis/lei_mostra_articulado. php?artigo_id $=109$ A0156\&nid $=109 \&$ tabela $=$ leis \& $-\overline{p a g i n a}=\overline{1} \&$ ficha $=1 \&$ 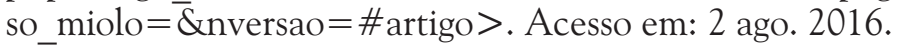 
PORTUGAL. Tribunal Constitucional. Constituição da República Portuguesa. Disponível em: < http://www.tribunalconstitucional.pt/tc/crp.html\#art26>. Acesso em: 3 ago. 2016.

PORTUGAL. Lei $\mathbf{n}^{\circ}$ 25/2012, de 16 de julho. Regula as diretivas antecipadas de vontade, sob a forma de testamento vital e procurador em cuidados de saúde, e cria o RENTEV. Disponível em: < https:/dre.pt/application/dir/ pdf1s/2012/07/13600/0372803730.pdf>. Acesso em: 27 jul. 2016.

RAPOSO, Vera Lúcia. Directivas antecipadas de vontade: em busca da lei perdida. Revista do Ministério Público, Lisboa, n. 125, p. 169-218, jan./mar. 2011.

RAPOSO, Vera Lúcia. Entre a vida e a morte: responsabilidade médica nas decisões em fim de vida. Revista Portuguesa de Direito da Saúde, Coimbra, ano 9, n. 18 p. 115-141, jul./dez. 2012.

RAPOSO, Vera Lúcia. No dia em que a morte chegar (decifrando o regime jurídico das diretivas antecipadas de vontade). Revista Portuguesa do Dano Corporal, Coimbra, ano 22, n. 24, p. 79-109, dez. 2013.

REGO, Fabiana. A força jurídica das declarações antecipadas de vontade. Revista Portuguesa de Direito da Saúde, Coimbra, ano 8, n. 16 p. 159-178, jul./dez. 2011.

RIBEIRO, Geraldo Rocha. Direito à autodeterminação e directivas antecipadas: o caso português. Revista Portuguesa de Direito da Saúde, Coimbra, ano 10, n. 19, p. 107-126, jan./jun. 2013.

SANTOS, Laura Ferreiro dos. Testamento vital: o que é? como elaborá-lo? Porto: Sextante Editora, 2011.

SOUSA, Rabindranath Capelo de. O direito geral de personalidade. Coimbra: Coimbra Editora, 2011.

VASCONCELOS, Pedro Leitão Pais de. A procuração irrevogável. 2. ed. Coimbra: Edições Almedina, 2016.

VASCONCELOS, Pedro Leitão Pais. A autorização. Coimbra: Coimbra Editora, 2012.

VASCONCELOS, Pedro Pais de. Direito de personalidade. Coimbra: Edições Almedina, 2014.

VÍTOR, Paula Távora. O apelo de Ulisses: o novo regime do procurador de cuidados de saúde na lei portuguesa. Julgar, Lisboa, número especial, p. 224248, jul. 2014.

VÍTOR, Paula Távora. Procurador para cuidados de saúde: a importância de um novo decisor. Revista Portuguesa de Direito da Saúde, Coimbra, ano 1, n. 1, p. 121-134, jan./jun. 2004. 
1 NUNES, Rui; MELO, Helena Pereira de. Testamento vital. Coimbra: Edições Almedina, 2011. p. 157.

2 PORTUGAL. Lei ${ }^{\circ}$ 25/2012, de 16 de julho. Regula as diretivas antecipadas de vontade, sob a forma de testamento vital e procurador em cuidados de saúde, e cria o RENTEV. Disponível em: < https:// dre.pt/application/dir/pdf1s/2012/07/13600/0372803730.pdf $\geq$. Acesso em: 27 jul. 2016.

3 NUNES, Rui; MELO, Helena Pereira de. Testamento vital. Coimbra: Edições Almedina, 2011. p. 123.

4 NUNES, Rui; MELO, Helena Pereira de. Testamento vital. Coimbra: Edições Almedina, 2011. p. 115, 122.

5 Artigo $70 .^{\circ}$ - Tutela geral da personalidade. 1. A lei protege os indivíduos contra qualquer ofensa ilícitaou ameaça de ofensa à sua personalidade física ou moral. 2. Independentemente da responsabilidade civil a que haja lugar, a pessoa ameaçada ou ofendida pode requerer as providências adequadas às circunstâncias do caso, com o fim de evitar a consumação da ameaça ou atenuar os efeitos da ofensa já cometida. Cfr, PORTUGAL. Procuradoria Geral Distrito de Lisboa. Código civil. Disponível em: <http://www. pgdlisboa.pt/leis/lei_mostra_articulado.php?artigo_id $=775$ A0070\&nid $=775 \&$ \&abela $=$ leis\&pagina $=1$ $\&$ ficha $=1 \&$ so ${ }_{\text {miolo }}=\&$ \&nversao $=\#$ artigo $\geq$. Acesso em: 1 ago. 2016.

6 SANTOS, Laura Ferreiro dos. Testamento vital: o que é? como elaborá-lo? Porto, Sextante Editora, 2011. p. 100.

7 SANTOS, Laura Ferreiro dos. Testamento vital: o que é? como elaborá-lo? Porto, Sextante Editora, 2011. p. 100-101.

8 ASSOCIAÇÃO PORTUGUESA DE BIOÉTICA. Parecer $\mathbf{n}^{\circ} \mathrm{P} / 05 / \mathrm{APB} / 06$ sobre as directivas antecipadas de vontade. p. 3. Disponível em: <http://www.apbioetica.org/fotos/gca/128025564711484713 46directivas medicas parec er 05.pdf>. Acesso em: 29 jul. 2016.

9 VÍTOR, Paula Távora. $\mathrm{O}$ apelo de Ulisses: o novo regime do procurador de cuidados de saúde na lei portuguesa. Julgar, Lisboa, número especial, p. 227-228, 2014.

10 COUNCIL OF EUROPE. Recommendation $n^{\circ} \mathbf{r}(99) 4$ of the commitee of ministers to member states on principles concerning the legal protection of incapable adults. Disponível em: $<$ http://www.coe. int/t/dg3/healthbioethic/texts_and_documents/Rec(99)4E.pdf $\geq$. Acesso em: 30 jul. 2016.

11 No Brasil, a figura do procurador de cuidados de saúde tem paralelo com o instrumento de mandato duradouro. Cfr. TESTAMENTO VITAL. Disponível em: <http://testamentovital.com.br/diretivas-antecipadas-de-vontade/>. Acesso em: 5 ago. 2016.

12 PINHEIRO, Jorge Duarte. As pessoas com deficiência como sujeitos de direitos e deveres: incapacidades e suprimento. Lisboa: Faculdade de Direito da Universidade de Lisboa, 2009. p. 13. Disponível em: $<$ http://www.icjp.pt/sites/default/files/media/600-886.pdf>. Acesso em: 3 ago. 2016.

13 COUNCIL OF EUROPE. Recommendation $\mathrm{cm} / \mathrm{rec}$ (2009) 11 of the committee of ministers to member states on principles concerning continuing powers of attorney and advanced directives for incapacity. Disponível em: <https://wcd.coe.int/ViewDoc.jsp?id=1563397\&Site=CM>. Acesso em: 30 jul. 2016.

14 VÍTOR, Paula Távora. O apelo de Ulisses: o novo regime do procurador de cuidados de saúde na lei portuguesa. Julgar, Lisboa, número especial, p. 228, 2014.

15 REGO, Fabiana. A força jurídica das declarações antecipadas de vontade. Lex Medicinae - Revista Portuguesa de Direito da Saúde, Coimbra, ano 8, n. 16, p. 162, jul./dez. 2011.

16 Artigo 26 - Outros direitos pessoais. 1. A todos são reconhecidos os direitos à identidade pessoal, ao desenvolvimento da personalidade, à capacidade civil, à cidadania, ao bom nome e reputação, à imagem, à palavra, à reserva da intimidade da vida privada e familiar e à protecção legal contra quaisquer formas de discriminação. 2. A lei estabelecerá garantias efectivas contra a obtenção e utilização abusivas, ou contrárias à dignidade humana, de informações relativas às pessoas e famílias. 3. A lei garantirá a dignidade pessoal e a identidade genética do ser humano, nomeadamente na criação, desenvolvimento e utilização das tecnologias e na experimentação científica. 4. A privação da cidadania e as restrições à capacidade civil só podem efectuar-se nos casos e termos previstos na lei, não podendo ter como fundamento motivos políticos. Cfr. PORTUGAL. Constituição da República Portuguesa. Disponível em: <http://www.tribunalconstitucional.pt/tc/crp.html\#art26>. Acesso em: 3 ago. 2016.

17 RAPOSO, Vera Lúcia. Entre a vida e a morte: responsabilidade médica nas decisóes em fim de vida. Revista Portuguesa de Direito da Saúde, Coimbra, ano 9, n. 18, p. 116, jul./dez. 2012.

18 VÍTOR, Paula Távora. Procurador para cuidados de saúde: a importância de um novo decisor. Revista Portuguesa de Direito da Saúde, Coimbra, ano 1, n. 1, p. 121, jan./jun. 2004.

19 REGO, Fabiana. A força jurídica das declarações antecipadas de vontade. Revista Portuguesa de Direito da Saúde, Coimbra, ano 8, n. 16, p. 159-160, jul./dez. 2011.; RAPOSO, Vera Lúcia. Directivas antecipadas de vontade: em busca da lei perdida. Revista do Ministério Público, Lisboa, n. 125, p. 208-210, jan./mar. 2011. 
20 NOVAIS, Jorge Reis. Renúncia a Direitos Fundamentais. In: MIRANDA, Jorge (Org.). Perspectivas constitucionais nos 20 anos da constituição de 1976. Coimbra: Coimbra Editora, 1996. v. 1. p. 327.

21 NUNES, Rui; MELO, Helena Pereira de. Testamento Vital. Coimbra: Edições Almedina, 2011, p. 31.

22 RAPOSO, Vera Lúcia. Directivas antecipadas de vontade: em busca da lei perdida. Revista do Ministério Público, Lisboa, n. 125, p. 206, jan./mar. 2011.

23 OLIVEIRA, Nuno. O princípio da dignidade da pessoa humana e a regulação jurídica da bioética. Revista Portuguesa de Direito da Saúde, Coimbra, ano 8, n. 15, p. 32, jan./jun. 2011.

24 BARBAS, Stela Marcos de Almeida Neves. Direito do genoma humano. Coimbra: Edições Almedina, 2007. p. 498.

25 NUNES, Rui. Consentimento informado e boa prática clínica. Julgar, Lisboa, número especial, p. 124, 2014.

26 No Código Civil brasileiro, encontramos solução paralela no art. $^{\circ} 15$.

27 ASSOCIAÇÃO PORTUGUESA DE BIOÉTICA. Parecer $\mathrm{n}^{\circ} \mathrm{p} / 05 / \mathrm{apb} / 06$ sobre as directivas antecipadas de vontade. p. 3. Disponível em: <http://www.apbioetica.org/fotos/gca/128025564711484713 46directivas medicas parec er 05.pdf>. Acesso em: 29 jul. 2016.

28 CONVENÇÃ̃O para a protecção dos direitos do homem e da dignidade do ser humano face às aplicações da biologia e da medicina: convenção sobre os direitos do homem e da biomedicina. Disponível em: $<$ http://www.gddc.pt/direitos-humanos/textosinternacionais-dh/tidhregionais/convbiologiaNOVO. html>. Acesso em: 27 jul. 2016.

29 Artigo 156 - Intervenções e tratamentos médico-cirúrgicos arbitrários. 1 - As pessoas indicadas no artigo 150 que, tendo em vista das finalidades nele apontadas, realizarem intervenções ou tratamentos sem consentimento do paciente são punidas com pena de prisão até 3 anos ou com pena de multa. 2 - O facto não é punível quando o consentimento: a) Só puder ser obtido com adiamento que implique perigo para a vida ou perigo grave para o corpo ou para a saúde; ou b) Tiver sido dado para certa intervenção ou tratamento, tendo vindo a realizar-se outro diferente por se ter revelado imposto pelo estado dos conhecimentos e da experiência da medicina como meio para evitar um perigo para a vida, o corpo ou a saúde; e não se verificarem circunstâncias que permitam concluir com segurança que o consentimento seria recusado. 3 - Se, por negligência grosseira, o agente representar falsamente os pressupostos do consentimento, é punido com pena de prisão até 6 meses ou com pena de multa até 60 dias. 4 - O procedimento criminal depende de queixa. Cfr. PORTUGAL. Código Penal. Disponível em: $<$ http:// www.pgdlisboa.pt/leis/lei_mostra_articulado.php?artigo_id=109A0156\&nid=109\&tabela $=$ leis\&pagi na $=1 \&$ ficha $=1 \&$ so_miolo $=\&$ \&nversao $=\#$ artigo $>$. Acesso em: 2 ago. 2016.

30 ASSOCIAÇÃO PORTUGUESA DE BIOÉTICA. Parecer $\mathrm{n}^{\circ} \mathrm{p} / 05 / \mathrm{apb} / 06$ sobre as directivas antecipadas de vontade. p. 9-11. Disponível em: <http://www.apbioetica.org/fotos/gca/128025564711484 71346directivas_medicas_parecer_05.pdf>. Acesso em: 29 jul. 2016.

31 ASSOCIAÇÃO PORTUGUESA DE BIOÉTICA. Parecer $\mathrm{n}^{\circ} \mathrm{p} / 05 / \mathrm{apb} / 06$ sobre as directivas antecipadas de vontade. p. 11. Disponível em: < http://www.apbioetica.org/fotos/gca/12802556471148471 346directivas_medicas_parecer_05.pdf>. Acesso em: 29 jul. 2016; RAPOSO, Vera Lúcia. Directivas antecipadas de vontade: em busca da lei perdida. Revista do Ministério Público, Lisboa, n. 125, p. 210-211, jan./mar. 2011; RAPOSO, Vera Lúcia. Entre a vida e a morte: responsabilidade médica nas decisões em fim de vida. Revista Portuguesa de Direito da Saúde, Coimbra, ano 9, n. 18, p. 116, jul./ dez. 2012.; RAPOSO, Vera Lúcia. No dia em que a morte chegar (decifrando o regime jurídico das diretivas antecipadas de vontade). Revista Portuguesa do Dano Corporal, Coimbra, ano 22, n. 24, p. 80-81, dez. 2013.

32 RAPOSO, Vera Lúcia. Directivas antecipadas de vontade: em busca da lei perdida. Revista do Ministério Público, Lisboa, n. 125, p. 210-211, jan./mar. 2011.

33 RAPOSO, Vera Lúcia. No dia em que a morte chegar (decifrando o regime jurídico das diretivas antecipadas de vontade). Revista Portuguesa do Dano Corporal, Coimbra, ano 22, n. 24, p. 80-81, dez. 2013.

34 CANOTILHO, Gomes; VITAL, Moreira. Constituição da República Portuguesa: artigos $1^{\circ}$ a 107. Coimbra: Coimbra Editora, 2014. p. 447.

35 Artigo 81. - Limitação voluntária dos direitos de personalidade. 1. Toda a limitação voluntária ao exercício dos direitos de personalidade é nula, se for contrária aos princípios da ordem pública. 2. A limitação voluntária, quando legal, é sempre revogável, ainda que com obrigação de indemnizar os prejuízos causados às legítimas expectativas da outra parte. Cfr. PORTUGAL. Código civil. Disponível em: <http://www.pgdlisboa.pt/leis/lei_mostra_articulado.php?artigo_id $=775 \mathrm{~A} 0081 \&$ nid $=775 \&$ tabel $\mathrm{a}=$ leis\&pagina $=1$ \& ficha $=1$ \&so_miolo $=\&$ \&nversao $=\#$ artigo $>$. Acesso em: 1 ago. 2016. 
36 Artigo 340 - Consentimento do lesado. 1. O acto lesivo dos direitos de outrem é lícito, desde que este tenha consentido na lesão. 2. O consentimento do lesado não exclui, porém, a ilicitude do acto, quando este for contrário a uma proibição legal ou aos bons costumes. 3. Tem-se por consentida a lesão, quando esta se deu no interesse do lesado e de acordo com a sua vontade presumível. Cfr. PORTUGAL. Código Civil. Disponível em: <http://www.pgdlisboa.pt/leis/lei mostra articulado.php?artigo id=775A0081 \&n $\mathrm{id}=775 \&$ tabela $=$ leis\&pagina $=1 \&$ ficha $=1 \&$ so $\operatorname{miolo}=\&$ Enversao $=\#$ artigo $>$. Acesso em: 1 ago. 2016.

37 MIRANDA, Jorge; MEDEIROS, Rui. Constituição portuguesa anotada, tomo I, artigos $1^{\circ}$ a $79^{\circ}$. Coimbra: Coimbra Editora, 2005. p. 259.

38 RAPOSO, Vera Lúcia. Directivas antecipadas de vontade: em busca da lei perdida. Revista do Ministério Público, Lisboa, n. 125, p. 210-211, jan./mar. 2011.

39 CARVAlHO, Orlando de. Teoria Geral do Direito Civil. 3. ed. Coimbra: Coimbra Editora, 2012. p. 102-106, 228.

40 OLIVEIRA, Nuno. O princípio da dignidade da pessoa humana e a regulação jurídica da bioética. Revista Portuguesa de Direito da Saúde, Coimbra, ano 8, n. 15, p. 29-33, jan./jun. 2011.

41 VASCONCELOS, Pedro Pais de. Direito de personalidade. Coimbra: Edições Almedina, 2014. p. 57, 64.

42 VASCONCELOS, Pedro Leitão Pais. A autorização. Coimbra: Coimbra Editora, 2012. p. 14-16; VASCONCELOS, Pedro Pais de. Direito de personalidade. Coimbra: Edições Almedina, 2014. p. 64.

43 PEREIRA, André Gonçalo Dias. O consentimento médico informado na relação médico-paciente. Coimbra: Coimbra Editora, 2004. p. 172-173.

44 SOUSA, Rabindranath Capelo de. O direito geral de personalidade. Coimbra: Coimbra Editora, 2011. p. $402-404$.

45 Artigo 157- Dever de esclarecimento. Para efeito do disposto no artigo anterior, o consentimento só é eficaz quando o paciente tiver sido devidamente esclarecido sobre o diagnóstico e a índole, alcance, envergadura e possíveis consequências da intervenção ou do tratamento, salvo se isso implicar a comunicação de circunstâncias que, a serem conhecidas pelo paciente, poriam em perigo a sua vida ou seriam susceptíveis de lhe causar grave dano à saúde, física ou psíquica. Cfr. PORTUGAL. Código Penal. Disponível em: <http://www.pgdlisboa.pt/leis/lei_mostra_articulado.php?artigo_id=109A0156\&nid $=109 \&$ tabela $=$ leis\&pagina $=1 \&$ ficha $=1 \&$ so miolo $=\&$ nversao $=\#$ artigo $>$. Acesso em: 2 ago. 2016.

46 Artigo 45 - Consentimento do doente. 1 - Só é válido o consentimento do doente se este tiver capacidade de decidir livremente, se estiver na posse da informação relevante e se for dado na ausência de coacções físicas ou morais. 2 - Sempre que possível, entre o esclarecimento e o consentimento deverá existir intervalo de tempo que permita ao doente reflectir e aconselhar-se. 3 - O médico deve aceitar e pode sugerir que o doente procure outra opinião médica, particularmente se a decisão envolver grandes riscos ou graves consequências. ORDEM DOS MÉDICOS. Código deontológico da ordem dos médicos. Disponível em: <https://www.ordemdosmedicos.pt/?lop=conteudo\&op=9c838d2e45b2ad1094d42f4 ef36 764f6\&id=cc42acc8ce334185e0193753adb6cb77> . Acesso em: 28 jul. 2016.

47 RAPOSO, Vera Lúcia. Entre a vida e a morte: responsabilidade médica nas decisões em fim de vida. Revista Portuguesa de Direito da Saúde, Coimbra, ano 9, n. 18, p. 115-116, 118, jul./dez. 2012.

48 VÍTOR, Paula Távora. Procurador para cuidados de saúde: a importância de um novo decisor. Revista Portuguesa de Direito da Saúde, Coimbra, ano 1, n. 1, p. 121, jan./jun. 2004.; RAPOSO, Vera Lúcia. Entre a vida e a morte: responsabilidade médica nas decisões em fim de vida. Revista Portuguesa de Direito da Saúde, Coimbra, ano 9, n. 18, p. 118, jul./dez. 2012.

49 RAPOSO, Vera Lúcia. Entre a vida e a morte: responsabilidade médica nas decisões em fim de vida. Revista Portuguesa de Direito da Saúde, Coimbra, ano 9, n. 18, p. 116-118, jul./dez. 2012.

50 Esta é, também, a solução prevista pelo legislador no Código Civil brasileiro, que no seu art. ${ }^{\circ} 11$ determina a intransmissibilidade e irrenunciabilidade dos direitos de personalidade, não se admitindo a limitação voluntária do seu exercício, salvaguardadas as exceções previstas na lei.

51 VASCONCELOS, Pedro Leitão Pais. A autorização. Coimbra: Coimbra Editora, 2012. p. 19.

52 VASCONCELOS, Pedro Pais de. Direito de personalidade. Coimbra: Edições Almedina, 2014. p. 60.

53 VASCONCELOS, Pedro Leitão Pais. A autorização. Coimbra: Coimbra Editora, 2012. p. 17-19, 124125.

54 VASCONCELOS, Pedro Leitão Pais. A autorização. Coimbra: Coimbra Editora, 2012. p. 24-25.

55 RAPOSO, Vera Lúcia. Directivas antecipadas de vontade: em busca da lei perdida. Revista do Ministério Público, Lisboa, n. 125, p. 177, jan./mar. 2011; RAPOSO, Vera Lúcia. Entre a vida e a morte: responsabilidade médica nas decisões em fim de vida. Revista Portuguesa de Direito da Saúde, Coimbra, ano 9 , n. 18, p. 120 jul./dez. 2012. 
56 As decisões do PCS, dentro dos limites da procuração que lhe foi concedida, prevalecem sobre as de qualquer outra pessoa, exceto as do próprio outorgante ( $\mathrm{n}^{\circ} 2$ art. $\left.^{\circ} 13 \mathrm{LDAV}\right)$. A força vinculativa da decisão do procurador de cuidados de saúde resulta do preenchimento dos requisitos formais constantes do $\mathrm{n}^{\circ} 1$ do art. $^{\circ} 3$ e $4^{\circ}$ da LDAV, sendo certo que os poderes conferidos ao representante assumem, por via de regra, a forma expressa em documento $\left(\mathrm{n}^{\circ} 1\right.$ art. $\left.^{\circ} 12 \mathrm{LDAV}\right)$.

57 VÍTOR, Paula Távora. Procurador para cuidados de saúde: a importância de um novo decisor. Revista Portuguesa de Direito da Saúde, Coimbra, ano 1, n. 1, p. 121, jan.jun. 2004.

58 As decisões do PCS, dentro dos limites da procuração que lhe foi concedida, prevalecem sobre as de qualquer outra pessoa, exceto as do próprio outorgante ( $\left.\mathrm{n}^{\circ} 2 \mathrm{art}^{\circ}{ }^{\circ} 13 \mathrm{LDAV}\right)$. A força vinculativa da decisão do procurador de cuidados de saúde resulta do preenchimento dos requisitos formais constantes do $\mathrm{n}^{\circ} 1$ do $^{\text {art. }}{ }^{\circ} 3$ e $4^{\circ}$ da LDAV, sendo certo que os poderes conferidos ao representante assumem, por via de regra, a forma expressa em documento ( ${ }^{\circ} 1$ art. $^{\circ} 12$ LDAV).

59 RAPOSO, Vera Lúcia. Directivas antecipadas de vontade: em busca da lei perdida. Revista do Ministério Público, Lisboa, n. 125, p. 177, jan./mar. 2011.; RAPOSO, Vera Lúcia. Entre a vida e a morte: responsabilidade médica nas decisões em fim de vida. Revista Portuguesa de Direito da Saúde, Coimbra, ano 9 , n. 18, p. 120, jul./dez. 2012.

60 ASSOCIAÇÃO PORTUGUESA DE BIOÉTICA. Estudo ${ }^{\circ}$ E/17/AAPB/10: testamento vital. p. 16. Disponível em: <http://www.apbioetica.org/fotos/gca/1284923005parecer-testamento_vital.pdf>. Acesso em: 4 ago. 2016.

61 VASCONCELOS, Pedro Leitão Pais. A autorização. Coimbra: Coimbra Editora, 2012. p. 19-20.

62 VASCONCELOS, Pedro Leitão Pais de. A procuração irrevogável. 2. ed. Coimbra: Edições Almedina, 2016. p. 6.

63 Artigo 265 - Extinção da procuração. 1. A procuração extingue-se quando o procurador a ela renuncia, ou quando cessa a relação jurídica que lhe serve de base, excepto se outra for, neste caso, a vontade do representado. 2. A procuração é livremente revogável pelo representado, não obstante convenção em contrário ou renúncia ao direito de revogação. 3. Mas, se a procuração tiver sido conferida também no interesse do procurador ou de terceiro, não pode ser revogada sem acordo do interessado, salvo ocorrendo justa causa. Cfr. PORTUGAL. Código Civil. Disponível em: <http://www.pgdlisboa.pt/ leis/lei_mostra_articulado.php?artigo_id $=775 \mathrm{~A} 0081 \&$ nid $=775 \&$ tabela $=$ leis\&pagina $=1 \&$ ficha $=1 \&$ so_miolo $=\&$ \&nversao $=\#$ artigo $>$. Acesso em: 1 ago. 2016.

64 FERNANDES, Luís Alberto Carvalho. Teoria geral do direito civil: fontes, conteúdo e garantia da relação jurídica. 4. ed. Lisboa: Universidade Católica Editora, 2007. v. 2. p. 252-253.

65 FERNANDES, Luís Alberto Carvalho. Teoria geral do direito civil: introdução e pressupostos da relação jurídica. 4. ed. Lisboa: Universidade Católica Editora, 2007. v. 1. p. 267.

66 Artigo 262 - Procuração. 1. Diz-se procuração o acto pelo qual alguém atribui a outrem, voluntariamente, poderes representativos. 2. Salvo disposição legal em contrário, a procuração revestirá a forma exigida para o negócio que o procurador deva realizar. Cfr. PORTUGAL. Código Civil. Disponível em: $<$ http:// www.pgdlisboa.pt/leis/lei_mostra_articulado.php?artigo_id=775A0081\&nid=775\&tabela $=$ leis\&pagin $\mathrm{a}=1$ \&ficha $=1$ \&so miolo $=$ \&nversao $=\#$ artigo $>$. Acesso em: 1 ago. 2016.

67 PEREIRA, André Gonçalo Dias. O consentimento médico informado na relação médico-paciente. Coimbra: Coimbra Editora, 2004. p. 133-137; VÍTOR, Paula Távora. Procurador para cuidados de saúde: a importância de um novo decisor. Revista Portuguesa de Direito da Saúde, Coimbra, ano 1, n. 1, p. 123-124, jan./jun. 2004.

68 PEREIRA, André Gonçalo Dias. O consentimento médico informado na relação médico-paciente. Coimbra: Coimbra Editora, 2004. p. 250-251; RIBEIRO, Geraldo Rocha. Direito à autodeterminação e directivas antecipadas: o caso Português. Revista Portuguesa de Direito da Saúde, Coimbra, ano 10, n. 19, p. 108-109, jan./jun. 2013.

69 Artigo 295 - Disposições reguladoras. Aos actos jurídicos que não sejam negócios jurídicos são aplicáveis, na medida em que a analogia das situações o justifique, as disposições do capítulo precedente. Cfr. PORTUGAL. Código Civil. Disponível em: < http://www.pgdlisboa.pt/leis/lei_mostra_articulado.php?artigo_id=775A008 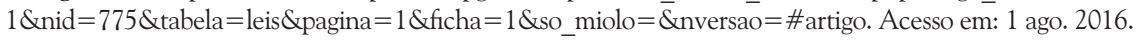

70 LOUREIRO, João Gonçalves. Metáfora do vegetal ou metáfora do pessoal? considerações jurídicas em torno do estado vegetativo crónico. Cadernos de Bio-Ética, Coimbra, n. 8, p. 41, dez. 1994.

71 ASSOCIAÇÃO PORTUGUESA DE BIOÉTICA. Parecer $\mathbf{n}^{\circ} \mathrm{P} / 05 / \mathrm{APB} / 06$ sobre as directivas antecipadas de vontade. p. 15. Disponível em: <http://www.apbioetica.org/fotos/gca/12802556471148471 346directivas_medicas_parec er_05.pdf>. Acesso em: 29 jul. 2016. 
72 PINHEIRO, Jorge Duarte. As pessoas com deficiência como sujeitos de direitos e deveres. incapacidades e suprimento. Lisboa: Faculdade de Direito da Universidade de Lisboa, 2009. p. 10. Disponível em: <http://www.icjp.pt/sites/default/files/media/600-886.pdf>. Acesso em: 3 ago. 2016.

73 VÍTOR, Paula Távora. Procurador para cuidados de saúde: a importância de um novo decisor. Revista Portuguesa de Direito da Saúde, Coimbra, ano 1, n. 1, p. 125, jan./jun. 2004.

74 Artigo 145- Dever especial do tutor. O tutor deve cuidar especialmente da saúde do interdito, podendo para esse efeito alienar os bens deste, obtida a necessária autorização judicial. Cfr. PORTUGAL. Código civil. Disponível em: < http://www.pgdlisboa.pt/leis/lei_mostra_articulado.php?artigo_id=775A0081\&n $\mathrm{id}=775 \&$ tabela $=$ leis\&pagina $=1 \&$ ficha $=1 \&$ so_miolo $=\&$ \&nversao $=\#$ artigo $>$. Acesso em: 1 ago. 2016

75 VÍTOR, Paula Távora. Procurador para cuidados de saúde: a importância de um novo Decisor. Revista Portuguesa de Direito da Saúde, Coimbra, ano 1, n. 1, p. 124, jan./jun. 2004.

76 Artigo 1620 - Casamento por procuração. 1. É lícito a um dos nubentes fazer-se representar por procurador na celebração do casamento. 2. A procuração deve conter poderes especiais para o acto, a designação expressa do outro nubente e a indicação da modalidade do casamento. Cfr. PORTUGAL. Código civil. Disponível em: <http://www.pgdlisboa.pt/leis/lei_mostra_articulado.php?artigo_id=775A0081\&nid= $775 \&$ tabela $=$ leis\&pagina $=1 \&$ ficha $=1 \&$ so $\_$miolo $=\&$ \&versao $=\#$ artigo $>$. Acesso em: 1 ago. 2016.

77 Artigo 1849 - Carácter pessoal e livre da perfilhação. A perfilhação é acto pessoal e livre; pode, contudo, ser feita por intermédio de procurador com poderes especiais. Cfr. PORTUGAL. Código civil. Disponível em: <http://www.pgdlisboa.pt/leis/lei_mostra_articulado.php?artigo_id $=775 \mathrm{~A} 0081 \&$ nid $=775 \&$ tabela $=$ leis\&pagina $=1 \&$ ficha $=1 \&$ so miolo $=$ \&nversao $=\#$ artigo $>$. Acesso em: 1 ago. 2016.

78 ASSOCIAÇÃO PORTUGUESĀ DE BIOÉTICA. Parecer $\mathbf{n}^{\circ}$ P/05/APB/06 sobre as directivas antecipadas de vontade. p. 15. Disponível em: < http://www.apbioetica.org/fotos/gca/12802556471148471 346directivas_medicas_parecer_05.pdf>. Acesso em: 29 jul. 2016.

79 Artigo $143-\bar{A}$ quem incumbe a tutela. 1. A tutela é deferida pela ordem seguinte: a) Ao cônjuge do interdito, salvo se estiver separado judicialmente de pessoas e bens ou separado de facto por culpa sua, ou se for por outra causa legalmente incapaz; b) À pessoa designada pelos pais ou pelo progenitor que exercer o poder paternal, em testamento ou documento autêntico ou autenticado; c) A qualquer dos progenitores do interdito que, de acordo com o interesse deste, o tribunal designar; d) Aos filhos maiores, preferindo o mais velho, salvo se o tribunal, ouvido o conselho de família, entender que algum dos outros dá maiores garantias de bom desempenho do cargo. 2. Quando não seja possível ou razões ponderosas desaconselhem o deferimento da tutela nos termos do número anterior, cabe ao tribunal designar o tutor, ouvido o conselho de família. Cfr. PORTUGAL. Código Civil. Disponível em: <http://www.pgdlisboa. pt/leis/lei_mostra_articulado.php?artigo_id $=775$ A0081 \&nid $=775 \&$ tabela $=$ leis \&pagina $=1 \&$ ficha $=1$ \&so_miolo $=\&$ nversao $=\#$ artigo $>$. Acesso em: 1 ago. 2016.

80 APB. Parecer $n^{\circ}$ P/05/APB/06 sobre as directivas antecipadas de vontade. p. 15. Disponível em $<$ http://www.apbioetica.org/fotos/gca/12802556471148471346directivas_medicas_parecer_05.pdf >. Acesso em: 29 jul. 2016.

81 VÍTOR, Paula Távora. Procurador para cuidados de saúde: a importância de um novo decisor. Revista Portuguesa de Direito da Saúde, Coimbra, ano 1, n. 1, p. 129-130, jan.jun. 2004.

82 ASSOCIAÇÃO PORTUGUESA DE BIOÉTICA. Estudo $\mathrm{n}^{\circ}$ E/17/AAPB/10 - testamento vital. p. 16. Disponível em: <http://www.apbioetica.org/fotos/gca/1284923005parecer-testamento_vital.pdf>. Acesso em: 4 ago. 2016.

83 LOUREIRO, João Gonçalves. Metáfora do vegetal ou metáfora do pessoal? considerações jurídicas em torno do estado vegetativo crónico. Cadernos de Bio-Ética, Coimbra, n. 8, p. 41, dez. 1994.

84 RAPOSO, Vera Lúcia. Entre a vida e a morte: responsabilidade médica nas decisões em fim de vida. Revista Portuguesa de Direito da Saúde, Coimbra, ano 9, n. 18, p. 118, jul./dez. 2012.

85 RAPOSO, Vera Lúcia. entre a vida e a morte: responsabilidade médica nas decisões em fim de vida. Revista Portuguesa de Direito da Saúde, Coimbra, ano 9, n. 18, p. 120-121, jul./dez. 2012.; RAPOSO, Vera Lúcia. Directivas antecipadas de vontade: em busca da lei perdida. Revista do Ministério Público, Lisboa, n. 125, p. 177, jan./mar. 2011.

86 PEREIRA, André Dias. Diretivas antecipadas de vontade em portugal. Julgar, Lisboa, número especial, p. 289, 2014.

87 RAPOSO, Vera Lúcia. Entre a vida e a morte: responsabilidade médica nas decisões em fim de vida. Revista Portuguesa de Direito da Saúde, Coimbra, ano 9, n. 18, p. 119-120, jul./dez. 2012. 


\section{ADVANCED DIRECTIVES OF WILL: NEW CHALLENGES FOR THE UNDERSTANDING OF THE LEGAL SYSTEM THROUGH THE RECOGNITION OF THE INSTITUTE OF VOLUNTARY REPRESENTATION IN MATTERS OF PERSONALITY RIGHTS}

\begin{abstract}
Early declarations of will were expressly recognized by the Portuguese legal framework upon the approval of Law $25 / 2012$, of July $16^{\text {th }}$. Such decision brought to light new challenges for understanding the legal system, namely by the recognition of voluntary representation regulation regarding healthcare. In a time when autonomy is increasingly valued, this instrument presents itself as a fruitful response mechanism to a specific incapacity, limited to the health area, i.e., an expression of will. Medical decisions focus on the fundamental core of a person's physical and psychic personality, which would initially determine the exercise of the right by its holder. It therefore encompasses a legal institute which is delicate in any field of law: personality rights. Personality rights form a person and protect their specific, concrete elements. Informed consent or dissent regarding medical interventions focuses precisely on such specific elements. Transmission of personality rights cannot arise from the limitation of said rights, even when the limitation is admitted pursuant to the provisions of article 81 of the Civil Code, because such rights are not transferable. In fact, and bearing in mind that power over personality assets can only belong to the person to which such assets are integrated, the appointment of healthcare proxies legitimizes the actions of third parties in regard to said personality assets, in a moment when the holder is not able to benefit from them or when their ability to do so is substantially reduced, thus being necessary that the representative exercise a certain power over such assets, in the specific area of health, in the interest of its respective holder.
\end{abstract}

Keywords: Advanced directives. Informed consent. Prospective autonomy. Power of attorney in cases of healthcare.

Submetido: 10 ago. 2016

Aprovado: 28 set. 2016 